\title{
THE INTERPRETATION OF A TERTIARY TILLITE AT MOUNT FEATHER, SOUTHERN VICTORIA LAND, ANTARGTIGA
}

\author{
By Howard Brady \\ (School of Biological Sciences, Macquarie University, North Ryde, New South Wales 2 I I3, Australia) \\ and BARRIE MCKelveY \\ (Department of Geology, University of New England, Armidale, New South Wales 235 I, Australia)
}

\begin{abstract}
A Tertiary tillite occurs at an altitude of $2750 \mathrm{~m}$ on Mount Feather in southern Victoria Land. The tillite mantles a remnant of the floor of a south-east-trending glacial valley that pre-dates the cutting of the existing glacial drainage system in southern Victoria Land. Petrographic evidence suggests that ice which deposited the tillite drained a relatively distant source area.

RÉsumÉ. L'interpretation d'une tillite tertiaire au Mount Feather, en Victoria Land du Sud, Antarctique. Une tillite tertiaire se trouve à une altitude de $2750 \mathrm{~m}$ au Mount Feather dans le Sud de la Victoria Land. La tillite recouvre un reste du lit d'une vallée glaciaire se dirigeant vers le Sud Est qui est antérieure à la coupure par l'actuel réseau d'écoulement des glaces du Sud Est de la Victoria Land. Les indices pétrographiques suggèrent que la glace qui a déposé la tillite drainait un bassin versant assez étendu.

Zusammenfassung. Die Deutung einer tertiären Moräne am Mount Feather, Süd-Victoria-Land, Antarktis. Am Mount Feather im südlichen Victoria-Land tritt in $2750 \mathrm{~m}$ Höhe eine tertiäre Moräne auf. Sie umschliesst einen Rest des Bodens eines nach Süd-Ost gerichteten Gletschertales, das älter ist als die Eintiefung des im südlichen Victoria-Land bestehenden glazialen Abflusssystems. Petrographische Hinweise lassen annehmen, dass das Eis, aus dem die Moräne stammt, aus einem relativ weit entfernten Quellgebiet abfloss.
\end{abstract}

\section{INTRODUCTION}

We wish to describe a Tertiary tillite exposed at an altitude of $2750 \mathrm{~m}$ overlooking Ferrar Glacier in the Transantarctic Mountains in southern Victoria Land. We believe this tillite provides important data concerning the early history in southern Victoria Land of the East Antarctic ice sheet. The tillite occurs as a gently inclined veneer up to $37 \mathrm{~m}$ thick, distributed over a vertical distance of $150 \mathrm{~m}$ on the north-east ridge of Mount Feather (2985 m), the highest peak in the Quartermain Mountains (part of the Transantarctic Mountains) (Fig. I). The tillite rests disconformably on unfolded Permian and Triassic strata of the Beacon Supergroup. The upper surface of the glacial deposit has been later swept by ice from adjacent cirques and formed into an undulating glacial bench with a surface area of $0.6 \mathrm{~km}^{2}$. The outcrop pattern clearly shows the tillite to pre-date the deep glacial sculpturing of the whole Mount Feather massif. On its southern side the bench surmounts a steep $700 \mathrm{~m}$ scarp overlooking Ferrar Glacier. Similarly, on its north-eastern side the bench drops precipitously I $000 \mathrm{~m}$ to the floor of Beacon Valley (Fig. 2).

This tillite has been previously examined by Mayewski (1972, 1975). A glacial direction was stated but no descriptions of the deposit were given. Mayewski considered the deposit to belong to the Sirius Formation, a tillite first described in the Beardmore Glacier area $650 \mathrm{~km}$ to the south (Mercer, 1972), and which Mayewski considered to post-date the glacial sculpturing of the Transantarctic Mountains by the Antarctic ice sheet. However, Mercer (1972, p. 432) considered his Sirius Formation to pre-date the Antarctic ice sheet. Mayewski (1975, p. 49) considered the tillite at Mount Feather to indicate a palaeo-ice-flow direction of east-north-east. It is with this flow-direction determination and the relative age of the tillite with respect to the sculpturing of the Transantarctic Mountains in southern Victoria Land that we would differ with Mayewski. We set out our data below.

\section{General Geology}

The tillite is composed of uniformly massive diamictite devoid of internal stratification. No other sediment types were observed. The dispersed framework component of greater than ro $\mathrm{mm}$ diameter ranges between 3 and $10 \%$ of the deposit. The largest clasts noted exceed $2 \mathrm{~m}$ and are invariably of 


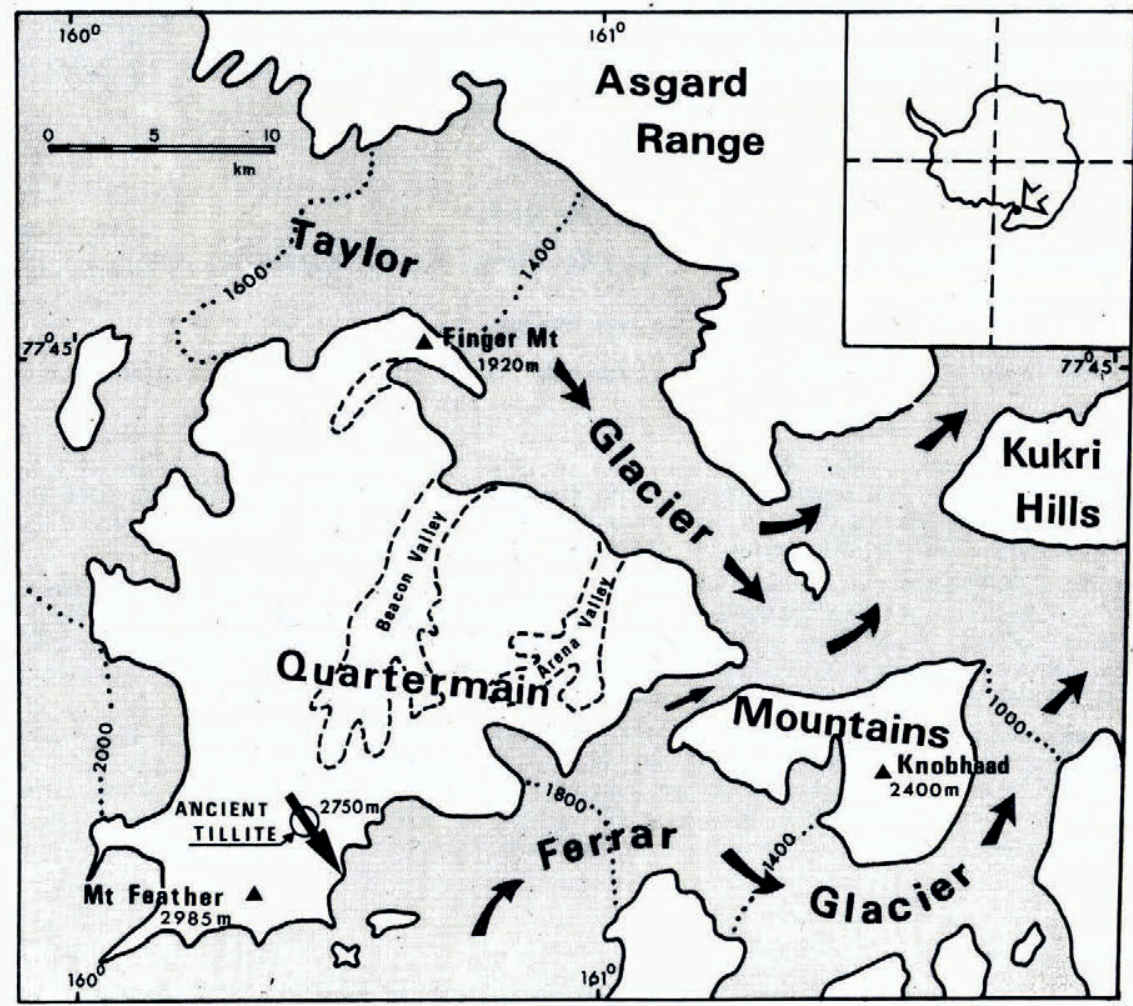

Fig. I. The location of Mount Feather in the Quartermain Mountains, southern Victoria Land. Taylor and Ferrar Glaciers descend from the Polar Plateau around the Quartermain Mountains and then flow east to the coast. The $16 \mathrm{~km}$ long deglaciated Beacon Valley was a former major tributary of Taylor Glacier. The position of the Tertiary tillite is indicated, together with the former ice-flow direction.

Jurassic Ferrar Dolerite. Several large boulders of the Beacon Supergroup Feather Conglomerate were noted, as also were a few of sandstones from the same cratonic sequence. The majority of the other (i.e. smaller) clasts consist of dolerite and pebbles from the Feather Conglomerate together with other Beacon Supergroup sandstones, siltstones, and coal (Fig. 3). Clasts of pre-Beacon Supergroup metasediments (i.e. basement complex rocks) were also noted. The colour of the diamictite matrix varies from medium light grey (N 6) to pale greenish yellow ( 10 Y 8/2), the former generally characteristic of fresh samples and the latter of weathered surfaces. The nature and colour of the matrix strongly suggest much of it to be inherited from the underlying Triassic Lashly Formation of the Beacon Supergroup.

Perhaps the two most striking features of the tillite are (i) the pronounced striations and faceting shown by many of the clasts and (ii) the strongly developed clast fabric. Striations are best developed on dolerite clasts but they are also clearly discernible on fine-grained sediments and even coal. Many clasts show more than one striation direction. Where individual striations are deeper at one end, this is generally the up-current direction. Striation azimuths measured on 57 clasts produced an average transport direction of $145^{\circ}$.

A conspicuous clast fabric is imparted by parallel alignment of the long axes of clasts. These similarly trend $145^{\circ}$, parallel to the striations. The clasts on first sight appear to be slightly imbricate in this direction with axial depressions of approximately $3^{\circ}$. However, when considering the attitude of the underlying striated pavement (see below), these inclined axes reflect nothing more than initial (primary) dip of the diamictite in that direction.

We succeeded in excavating two small exposures of the underlying striated pavement, beneath the highest and lowest exposures of the tillite, respectively. The upper pavement exposure dipped eastward 


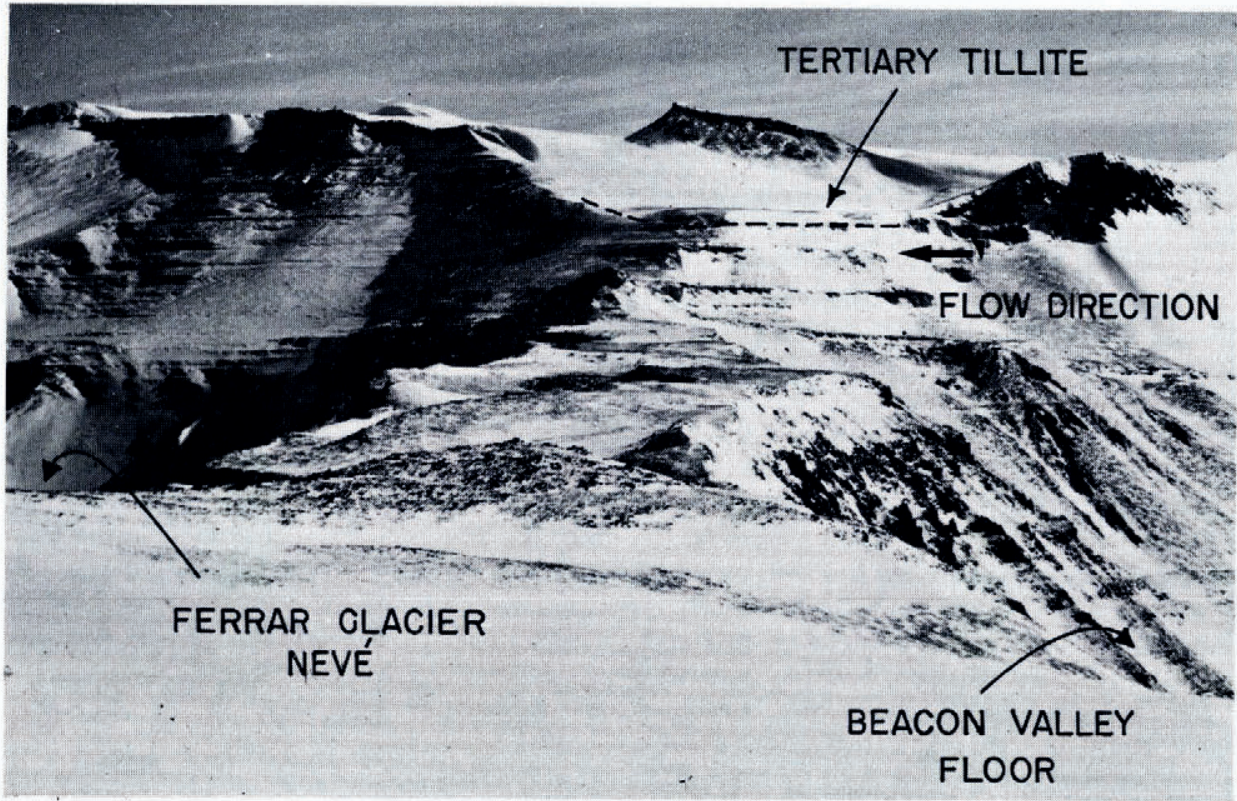

Fig. 2. View looking along the north-east ridge of Mount Feather towards the summit tableland. The glacial bench composed of the Tertiary tillite has been swept and cut by ice from the bordering cirque beyond. The disconformity between the tillite and the underlying Beacon Supergroup strata is indicated. On its southern (left) side, the bench drops abruptly $700 \mathrm{~m}$ to Ferrar Glacier. On its northern side, the bench stands 1 ooo $m$ above the floor of Beacon Valley. The palaeo-ice-flow direction of $145^{\circ}$ indicated by the tillite is very approximately at right-angles to the trend of the ridge.

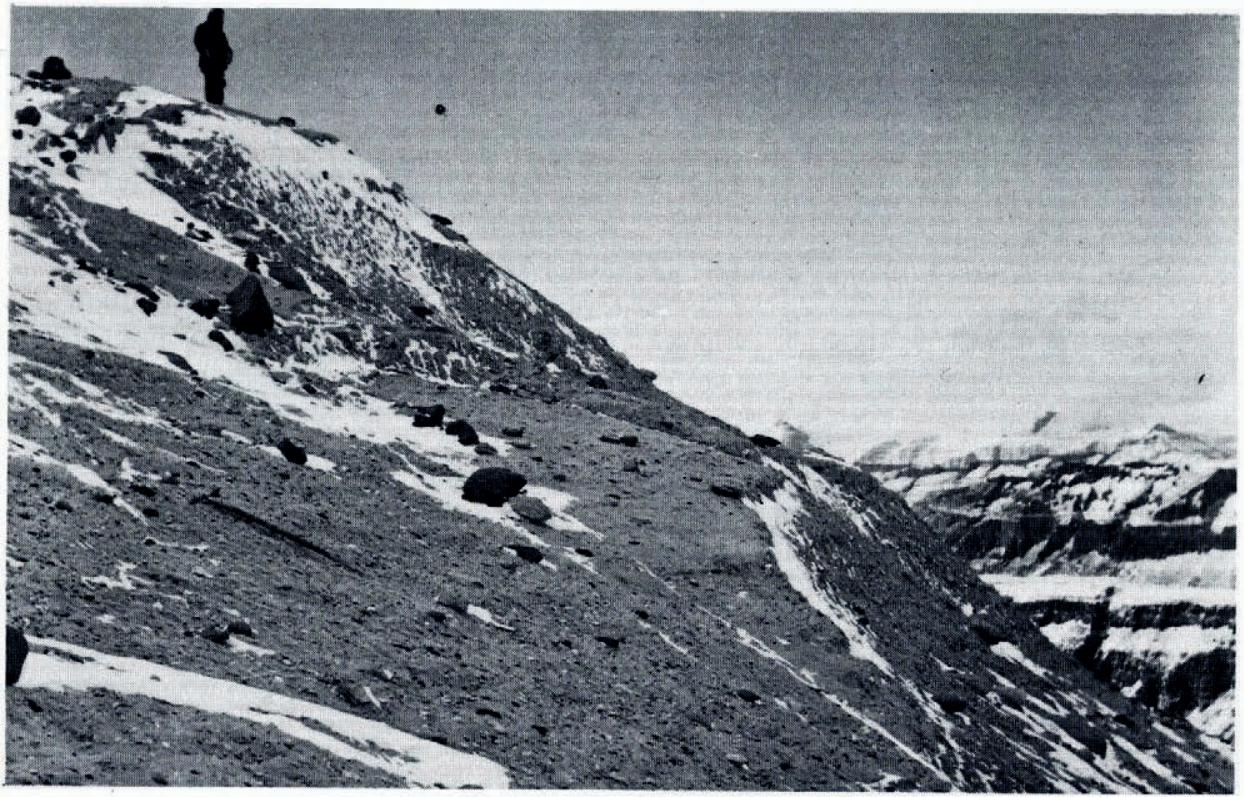

Fig. 3. An eroded scarp of the Tertiary tillite exposed on the north-east ridge of Mount Feather at approximately $2750 \mathrm{~m}$. The initial dip of the deposit is reflected by the inclined attitude of many of the clasts embedded in the sandy diamictite matrix. The dark clasts are of Jurassic Ferrar Dolerite. Other common clast types present include quartz-conglomerate, sandstones, and coal, all derived from the Devonian to Triassic Beacon Supergroup. 
at $17-20^{\circ}$. Striations on the pavement (three readings) trended $145^{\circ}$ and a pebble resting on the pavement exhibited striations trending $150^{\circ}$. However, a faceted pebble (within the underlying Palaeozoic sequence and so forming part of the pavement surface) did show a deep striation trending approximately $045^{\circ}$. The lower pavement fragment appeared only slightly inclined and we could not determine accurately its attitude. Striations upon it (12 readings) trended between $122^{\circ}$ and $127^{\circ}$.

The distribution of the tillite-Beacon Supergroup contact, the inclination of the higher pavement fragment, and the fabric of the striated clasts all suggest the tillite to be mantling the floor and western wall of a remnant of an ancient glacial valley that trended approximately $145^{\circ}$. The fact that the tilliteBeacon Supergroup contact descends $28 \mathrm{~m}$ in $700 \mathrm{~m}$ in this direction means the valley floor slopes at $2^{\circ}$ towards the south-east, a feature fully compatible with both the clast fabric and striation data.

We consider the striated surface underlying the tillite to be a remnant of a fossil valley floor and not a fossil cirque floor for the following reason. Neither the metasedimentary pebbles nor the lumps of coal within the tillite could be derived from the Mount Feather area by cirque erosion. Beacon Supergroup coal seams (Weller Coal Measures) occur at least $200 \mathrm{~m}$ beneath the tillite; the nearest exposed basement rocks occur approximately $\mathrm{I} 350 \mathrm{~m}$ beneath the tillite, $20 \mathrm{~km}$ to the north-east. Taking into account the palaeo-ice-flow trend to the south-east, we consider the source of the basement clasts would have been in the order of some tens of kilometres inland, beneath the present East Antarctic ice sheet. Drewry (in press), on evidence from radio echo-sounding data suggested the subglacial occurrence of basement rocks approximately $100 \mathrm{~km}$ inland from the plateau edge.

\section{Discussion}

At present there are no data to suggest a definite age of the tillite. However, its considerable antiquity is obvious, for the trend of the fossil valley infilled by the tillite is markedly discordant with the present glacial drainage system. This is particularly apparent when comparison of the trend of the fossil valley is made with that of the adjacent deeply incised Beacon Valley (Figs I and 2). Clearly, the fossil-valley fragment at Mount Feather pre-dates the cutting of the existing glacier-valley system in the area, and presumably therefore at least much of the Upper Tertiary-Quaternary Victoria orogeny of Gunn and Warren (1962, p. 56) that uplifted the Transantarctic Mountains. Unfortunately the age of the onset of the Victoria orogeny is not yet known.

A minimum age for the tillite is indicated by the presence of $7-10$ Ma diatom floras (Brady, in press) at Lake Vanda in Wright Valley, approximately $54 \mathrm{~km}$ north-east of Mount Feather. These have been subsequently uplifted during later movements of the Victoria orogeny. (Tectonic movements continued in the Pliocene for Webb and Wrenn (in press) have described uplifted mid-Pliocene benthonic fjord faunas in the adjacent Taylor Valley.) The Wright Valley floras clearly post-date the cutting of Wright "fjord", which is part of the present ice-drainage system. The tillite then is definitely older than 7-10 Ma, i.e. older than late Miocene.

It is difficult to place a maximum age on the tillite at Mount Feather. The earliest evidence of ice rafting in the Ross Sea (site 270 , Deep Sea Drilling Project) has been dated recently at $25 \mathrm{Ma}$ or latest Oligocene (Hayes and others, 1975). Should these data reliably reflect the onset of glaciation in East Antarctica, then the Mount Feather tillite can confidently be regarded as of early or Middle Miocene age. However, at present there is negligible ice rafting off much of Antarctica so such an assumption is not necessarily valid.

We note that Stuckless (1975, p. 27) recorded an apatite fission-track date from the Vida granite in Victoria Valley ( $14 \mathrm{~km}$ north-east of Lake Vanda) that suggests uplift $50 \mathrm{Ma}$ ( $\pm 10 \mathrm{Ma}$ ) ago. This date may well represent the onset of the Victoria orogeny (much earlier than envisioned by Gunn and Warren (1962)) and conceivably glaciation was a consequence of the uplift. This alternative is admittedly rather extreme and, with the limited data to hand, we consider the early or Middle Miocene date to be at present the more probable.

In that it precedes the glacial sculpturing of the Transantarctic Mountains in southern Victoria Land, the Mount Feather tillite conforms with Mercer's (1972) definition of his Sirius Formation. It does not post-date the cutting of the Transantarctic Mountains, as contended by Mayewski. However, we would suggest that for the present Mercer's term Sirius Formation be confined to those Tertiary glacigene sediments occuring in the Beardmore Glacier area. In all probability, Tertiary tillite remnants of various ages are widespread in the Transantarctic Mountains and we feel correlations should not yet be attempted until more stratigraphical data are to hand. 
Barrett and Powell (in press) have described a diverse sequence of Cenozoic glacigene sediments at Table Mountain, $36 \mathrm{~km}$ to the east of Mount Feather. We hesitate to suggest correlation for the following two reasons. These strata at Table Mountain occur on a glacial bench adjacent and parallel to the present-day Ferrar Glacier valley, i.e. their distribution is compatible with the existing glacial drainage system. Presumably then these deposits are younger than the tillite at Mount Feather. Furthermore, the Table Mountain strata lack the basement complex metasedimentary contribution present in the Mount Feather tillite and are clearly of local derivation, from a terrain where there was no basement complex exposed. In contrast, the metasediments in the older Mount Feather tillite reflect ice draining a much more distant inland source area where basement rocks were exposed.

\section{ACKNOWLEDGements}

This research was supported by National Science Foundation grant DPP-74-22894 directed by P. N. Webb of Northern Illinois University, by a University of New England research grant to B. C. McKelvey and by the Victoria University of Wellington (New Zealand) Antarctic Expedition No. 22 (1977-78).

MS. received 8 fune 1978

\section{REFERENCES}

Barrett, P. J., and Powell, R. D. In press. Mid Cenozoic glacial beds at Table Mountain, southern Victoria Land. (In Craddock, C., ed. Antarctic geoscience. Proceedings of the third Symposium on Antarctic Geology and Geophysics, Madison, 22-27 August, 1977. Madison, University of Wisconsin Press.)

Brady, H. T. In press. Late Cenozoic history of Taylor and Wright valleys and McMurdo Sound derived from diatom biostratigraphy and paleoecology of DVDP cores. (In Craddock, C., ed. Antarctic geoscience. Proceedings of the third Symposium on Antarctic Geology and Geophysics, Madison, 22-27 August, 1977. Madison, University of Wisconsin Press.)

Drewry, D. J. In press. Ice flow, bedrock and geothermal studies inland of McMurdo Sound, Antarctica. (In Craddock, C., ed. Antarctic geoscience. Proceedings of the third Symposium on Antarctic Geology and Geophysics, Madison, 22-27 August, 1977. Madison, University of Wisconsin Press.)

Gunn, B. M., and Warren, G. 1962. Geology of Victoria Land between the Mawson and Mulock glaciers, Antarctica. New Zealand. Geological Survey. Bulletin 71.

Hayes, D. E., and others. 1975. Initial Reports of the Deep Sea Drilling Project (Scripps Institution of Oceanography, University of California), Vol. 28. [Volume is by 12 authors.]

Mayewski, P. A. 1972. Glacial geology near McMurdo Sound and comparison with the central Transantarctic Mountains. Antarctic Journal of the United States, Vol. 7, No. 4, p. $103-06$.

Mayewski, P. A. 1975. Glacial geology and late Cenozoic history of the Transantarctic Mountains, Antarctica. Ohio State University. Institute of Polar Studies, Report No. 56.

Mercer, J. H. 1972. Some observations on the glacial geology of the Beardmore Glacier area. (In Adie, R. J., ed. Antarctic geology and geophysics. Symposium on Antarctic geology and solid earth geophysics, Oslo, 6-15 August I97o. Oslo, Universitetsforlaget, p. 427-33.)

Stuckless, J. S. I 975. Geochronology of core samples recovered from DVDP 6, Lake Vida, Antarctica. Dry Valley Drilling Project. Bulletin No. 6, p. 27.

Webb, P. N., and Wrenn, J. H. In press. Late Cenozoic micropalaeontology and biostratigraphy of eastern Taylor Valley, Antarctica. (In Craddock, C., ed. Antarctic geoscience. Proceedings of the third Symposium on Antarctic Geology and Geophysics, Madison, 22-27 August, 1977. Madison, University of Wisconsin Press.) 